представляє собою особливим чином сконструйовано систему навчання в інтернет-середовищі. Відбір і організація змісту навчання іноземної мови студентів немовних спеціальностей в дистанційному режимі залежать від мети, вибору моделі дистанційного навчання, можливостей програмного забезпечення, компетентності педагогічних кадрів та готовності учасників освітнього процесу до взаємодії у мережі.

\title{
Література:
}

1. Бутиріна М. В. Теоретичні основи дистанційного навчання у галузі технологічної освіти України [Електронний ресурс] / М. В. Бутиріна, О. О. Бондаренко, М. Г. Погорєлов // Режим доступу: http://www.nbuv.gov.ua/old_jrn/Soc_Gum/Vchdpu/ped/2012_97/Butyr.pdf.

2. Петренко Л. М. Сучасні тенденції модифікацій педагогічних технологій в освіті дорослих / Лариса Михайлівна Петренко // Витоки педагогічної майстерності: зб. наук. праць / Полтав. нац. пед. ун-т імені В. Г. Короленка. - Полтава, 2013. Вип. 11. - С. 256-261. (Серія «Педагогічні науки»).

DOI https://doi.org/10.30525/978-9934-26-114-5-56

\section{РОЗГЛЯД МАЙБУТНІМИ РЕДАКТОРАМИ НОРМАТИВНИХ АСПЕКТІВ ПЕРЕКЛАДУ В ПРОЦЕСІ ГЕРМЕНЕВТИЧНОГО АНАЛІЗУ ТЕКСТІВ}

\author{
Мішеніна Т. М. \\ професор кафедри украӥнської мови \\ Криворізький державний педагогічний університет \\ Качайло К. А. \\ доиент кафедри украӥнської мови \\ Криворізький державний педагогічний університет \\ м. Кривий Ріг, Дніпропетровска область, Украӥна
}

Фахова підготовка майбутніх редакторів орієнтована на вивчення низки дисциплін, які забезпечують не лише засвоєння знань, які стосуються понятійно-категорійного апарату редакційно-видавничої й колекційної діяльностей, але й знання, які становлять основу теорії i практики перекладу. Оскільки редагування освітніх видань передбачає діагностування мовних девіацій, подальше їх усунення на основі алгоритму редагування типу помилок (фонетико-орфоепічних, 
морфологічних, лексико-фразеологічних, синтаксичних, стилістичних), необхідним є спостереження над мовним матеріалом, у якому помилки зумовлені некоректним перекладом (вибір адекватного, буквального, вільного перекладів мають апелювати до особливостей перекладуваного тексту). Ознайомлення студентів з основними поняттями загальної та спеціальних теорій перекладу, основами редагування перекладу й основами перекладацької діяльності в медіа-структурах суттєво підвищують якість корекційної діяльності у змісті академічного дискурсу.

Задля здійснення якісного редакційного аналізу, редактор має володіти функціональною грамотністю, яка полягає в застосуванні типів перекладацьких еквівалентностей і відповідників залежно від стильової приналежності текстів; особливостей перекладуваних лексичних груп (наприклад, особливості перекладу власних (географічних) назв апелює до чинного правопису національних мов, де має враховуватися фонетико-орфоепічний корелят при перекладі); урахуванні особливостей перекладу різних груп лексичних і фразеологічних одиниць (наприклад, переклад синонімів, інтеронімів і паронімів в текстах слов'янських мов / германських мов); урахуванні особливості передачі граматичних значень при перекладі (наприклад, при перекладі іменників з російської українською мовою низка іменників мають різні граматичні ознаки роду, відповідне подальше узгодження іменника 3 прикметником у слов'янських мовах має свою реалізацію на рівні синтаксичних одиниць); застосування основних лексичних і граматичних перекладацьких трансформацій; апелящія до особливостей перекладу текстів різних стилів [1, с. 28-30; 2, с. 78-79].

Сукупність вимог, які висуваються до якості перекладу, називається нормою перекладу (прагматичну, конвенціональну, норму еквівалентності). Якість перекладу визначають мірою його відповідності перекладацькій нормі i характером неусвідомлених чи свідомих відхилень від цієї норми.

Герменевтичний аналіз текстів, які редагуються, передбачає урахування типу еквівалентності, що визначається як співвідношенням одиниць вихідної мови і мови перекладу, так і врахуванням прагматичних чинників, що впливають на акт перекладу (матеріальна культура (національні символи, традиційне житло, господарське начиння, знаряддя праці, їжа та напої, національне вбрання, осередки громадського спілкування); суспільні ритуали та звичаї (сімейні звичаї та обряди, календарні свята й обряди, трудові обряди й свята); організація суспільства (сім'я, рід, господарська діяльність, ремесла й промисли); знання про світ і природу (астрономія, метеорологія, 220 
демонологія, флора, фауна); кількість і рахунок (математика, метрологія); здоров'я людини та тварини (народні цілителі, хвороби); етикет (вітання, побажання (віншування), стосунки у сім’ї тощо); абстрактні поняття (доля, недоля, горе, щастя, правда, брехня, добробут, бідність тощо).

Зрозумілим є те, що розглядуваний аспект безпосередньо стосується перекладу еквівалентної й безеквівалентної лексики.

3 іншого боку, точний переклад може бути визнаний адекватним, якщо завдання перекладу полягає в передачі фактичної інформації про навколишній світ. Еквівалентний переклад завжди має бути точним, а точний переклад за визначенням лише частково еквівалентним (з урахуванням міжнародних термінів): Абсолютний - безвідносний, повний, цілковитий. Абстрактний - загальний, ідеальний, умоглядний. Авторитетний - змістовний, солідний, вагомий. Грандіозний - кардинальний, великий, вагомий, значний, визначний, цінний, дорогочінний, історичний, епохальний, значущзий.

Герменевтика перекладуваного тексту стосується також особливостей перекладу шляхом застосування таких засобів, як субституція (заміщеення одного іншим, подібним за властивостями або призначенням), інтерпретація (розкриття змісту чого-н.), парафрази (переказ думок, змісту якогось твору (виразу).

Прикладом може слугувати переклад, який містить мовні одиниці із яскраво позначеним національно-культурним забарвленням, такому перекладу має передувати співвідносний образний відповідник: пор. фразеологізми з топонімами: (укр.) На городі бузина, а в Києві дядько, Розуму і в Києві не купиш, Язик до Києва доведе; (рос.) Москва от копеечной (денежной) свечки сгорела (загорелась), Москва веками строилась, Москва людна и хлебна.

Українська й російська лінгвокультури репрезентують синонімічні ФО, до структури яких входять різні чоловічі й жіночі антропоніми: характеристика мовлення (Мели, Емеля, твоя неделя // Блей, пане Свириде, побачим, щзо з того вийде / Говорив Мирон рябої кобили сон / Говори, Климе, нехай твоє не гине / Балакайте, Гапко, бо я люблю слухать / Химині кури / Мотрині яйця / Мели, Денисе, погода тягне / Мели, Іване, доки вітру стане / Правда Сидорова - киселем млинці помазані, на паркані сушаться - негативна або глузлива характеристика мовлення когось, що характеризується беззмістовністю, нелогічністю, незначущістю, викривленням фактів тощо).

Статистика засвідчує, що, наприклад, в українській i польській мові на рівні паралельної функційності уживаються структури 3 атрибутивним членом, тоді як у російській мові такі конструкції не $\epsilon$ 
нормативними: рок-еженедельник / czasopismo rockowe рок-фестиваль festiwal rockowy / nоп-музыка тиzуkа ророwа.

Екстралінгвістичний чинник (суспільно-культурні й економічні зміни) зумовлюють номінацію, яка становить гібридне утворення, модель, яка базується на елементах греко-латинського походження (аудіоапаратура / audiosprzęt, біопаливо / biopaliwo, єврокомпроміс / eurokompromis, фотошпалери / фотообои / fototapeta; телеподія / телесобытие); екосистема; етновечір / морфологічний аналітизм systema eko; wieczór etno.

Концепція сучасних альтернативних словників апелює до відновлення національної традиції, водночас під час послуговування такими замінниками слід зважати на структурно-семантичну відповідність, наявність додаткових конотацій, полісемічність термінів, ураховувати те, що альтернативний дублет не завжди є точним за структурою і семантичним навантаженням, пор: авіадесант / літаковисадка; авіапарк / літакомайдан; автомат / саморух, самопал; агроном / рільничознавеиь; агрономія / рільничознавство; астрогнозія / зорезнавство; астронавт / зорелетун; макрокосм / всесвіт; мікрокосм / дрібносвіт; некрополь / кладовище, могильнище; орнітографія / птахоопис; орнітологія / птахознавство; палеографія / давнєписьмознавство; фотоапарат / світлячка; фотограф / світляк; фотографія / світлина.

Віднайдення оптимального варіанту перекладу в умовах глобалізації має апелювати до збереження автохтонності лінгвокультури, використання іншомовного відповідника може бути обгрунтованим за умови його кодифікації: Польсько-українські інтероніми (czlowiek (польськ.) / людина (укр.), пор. те̨і்сzуzпа (польськ.) / чоловік (укр.); gromada (польськ.) / зграя, скупчення (укр.), пор. społeczność, gmina / громада; kraina (польськ.) / область (укр.), пор. kraj (польськ.) / країна, край; земля (укр.); leczус́ (польськ.) / лікуватися, пор. liczyć, kalkulować, rachować (польськ.) / лічити (укр.))

На сучасному етапі розвитку термінознавства тенденціями у практиці перекладу $є$ шляхи віднайдення перетворення загальномовної лексики на термінологічну, визначення ролі такого перетворення у становленні наукового співтовариства. Тенденції розвитку терміносистеми простежуються у варіантних (формально-структурні, ономасіологічні варіанти) і синонімічних відношень між термінами (поняттями). Установлено закономірність: формальна й ономасіологічна варіативність визначається мовною можливістю виражати логікомисленнєві категорії різними мовними засобами.

Інтердискурсивність текстів глобальної культури інтенсифікують також жанрову гібридизацію текстів, що виявляється в поєднанні ознак 
різних жанрів, семіотичних кодів і функціональних стилів. Герменевтика текстів базується на таких типах мовних девіацій: 1. Помилки, які становлять суттєві і змістові відхилення від змісту оригіналу. 2. Помилки, які призводять до неточного відтворення смислу оригіналу, але не спотворюють його повністю. 3. Помилки, які не порушують загального змісту оригіналу, але знижують якість тексту перекладу внаслідок відхилення від стилістичних норм мови перекладу, використання маловживаних у певному тексті одиниць, зловживання запозиченнями тощо. 4. Порушення обов'язкових норм мови перекладу, які не впливають на еквівалентність перекладу, але свідчать про недостатнє володіння перекладачем певною мовою чи про його невміння подолати вплив мови оригіналу. Помилки цього роду надають підстави говорити про загальномовну культуру й грамотність перекладача.

\title{
Література:
}

1. Коптілов В. Теорія і практика перекладу : навчальний посібник. Київ : Юніверс, 2002. 280 с.

2. Корунець I. В. Теорія і практика перекладу (аспектний переклад) : підручник. Вінниця : Нова книга, 2001. 448 с.

DOI https://doi.org/10.30525/978-9934-26-114-5-57

\section{ОСНОВНІ НАПРЯМИ ФОРМУВАННЯ АНГЛОМОВНОЇ ФОНЕТИЧНОЇ КОМПЕТЕНТНОСТІ МАЙБУТНІХ УЧИТЕЛІВ ПОЧАТКОВОЇ ШКОЛИ}

\author{
Моляка I. B. \\ аспірантка кафедри педагогіки й психологї \\ Глухівський національний педагогічний університет \\ імені Олександра Довженка \\ м. Глухів, Україна
}

Сучасність педагогічного простору має нині новий виклик дистанційне навчання, яке поперемінно чергується 3 офлайн режимом роботи закладів освіти. До цього вчені й педагоги початкової освіти розробляли методи й підходи в діяльності нової української школи, маючи на меті, підготувати покоління вчителів, які зможуть реалізувати основні цілі навчання у початковій школі - формування 